\title{
2-4マルチメディアとアニメ
}

潮 永 光 生 ${ }^{\dagger}$

\section{CD-ROM におけるアニメーションの有用性}

現在, CD-ROM 作品の中にはかなりの頻度でアニ メーションが使われている。 その使われ方は様々であ り，また自由でもある．

（1）モデリング・レンダリングによる $3 \mathrm{D}$ アニメ ーション

(2) 様々な素材（イラストレーション, 写真, 図 版，実撮動画）をコンピュータ上で加工した 2 Dアニメーション

（3）アニメータがCD-ROMクリエータの一人と して介在するDTA（デスクトップアニメーシ ヨン)

（4）テレビアニメ, VP (ビデオパッケージ) アニ メ，劇場アニメなどを QuickTimeや MPEG などでそのままディジタイズしたもの

( 1 ) ～( 3 ) はアニメーションで動くもの自体をコン ピュータ上でオブジェクトとして扱うことが可能で, オブジェクトごとの動きの管理や “click \& go”によ るインタラクティビティの付加など, CD-ROM メデ イアの機能にマッチしたアニメーション手法といえ る.さらに現在のパソコンのパフォーマンス的な制限 を考えると, 色数や動画エリアのハンドリングの上で も, (1)〜 ( 3 )のアニメーションは, CD-ROM 夕イ トル制作においてかなり有利だといえよう.

一方，(4)の Quick Timeや MPEG によるアニメ ーション素材は $(1) 〜(3)$ とは全く意味が異なる.す なわち, パソコン上でビデオを再生しているに過ぎ ず，もはや動くものをばらばらにオブジェクトとして は扱うことができないのである。この場合は既存のア ニメーション素材の 2 次的使用, または動画のクオリ ティを優先させたり, 映像と音とのシンクロをはかる には有用である。いずれにせよ, パソコンをステージ とした作品の中にはアニメーションがあふれているの

† 株式会社 愛があれば大丈夫 空想科学事業部

“2-4 Multimedia and Animation” by Mitsuo Shionaga (A V Computer Software Dept., AI ga areba Daijobu Co., Ltd., Tokyo)
である。

しかし，これだけ CD-ROM 制作においてアニメー ションが必要とされながら, コンピュータデザイナが 手探りでアニメーション作業を行っているというのが ほとんどである。様々なメディアを統合する $\mathrm{CD}^{-}$ ROM 制作現場には, 各分野のスペシャリスト, クリ エータたちが集い, 個性をダイレクトにぶつけ合う. しかしアニメーションの場合，アニメータ個人の姿が 見えてこないのだ.

\section{2. アニメとマルチメディアの不透明な距離}

私のイメージの中では“アニメーション”と“アニ メ”の違いが明確に認識されている。“アニメーショ ン”とは絵や立体を動かす手法のことであり, グラフ イックデザインの映像軸方向への発展型, すなわち表 現の幅である。一方, “アニメ”という場合, その手 法だけではなく商品形態までをも決定する.

この違いは“ワープロソフト”と“ワープロ機”の 違いに似てはいないだろうか。まさに過渡期であるパ ソコン上で, 数あるソフトの中から必要に応じて選ば れる“ワープロソフト”。一方，キーをたたいて，文章 を作成・印刷するという手法が，そのまま商品形態で ある明確で安定した家電製品 “ワープロ機”.

“アニメ”もまた明確な商品の色を持ち, 確実なマ 一ケットを持つ. 前提である手法は変わりようがな く, したがって, 制作ラインを崩すことは容易ではな い. 膨大なセル作業においては人海戦術を必須とし て，それぞれが量の論理のなかでスケジュールと戦 う.さらに, 原作のアニメーション化権やキャラクタ 権の獲得によるビジネス展開が大きな原動力となりう る, ビジネス構造が確立されている。この制作システ ムから, キャラクタビジネスまで含めた大きな“アニ メ会社”では，その性格上，“個”が見えにくい.

しかし，このような状況はなにもアニメだけではな い. 程度の差こそあれ, 映像ビジネス全体にもいえる ことなのだ。“商品”と“作品”の狭間で葛藤しなが らも, エンタテイメントビジネスの中にいる以上, 自 らも構造の一部を担っているのである. 
このどうしようもない現実の中，音や映像を扱える パーソテルコンピュータの登場が一筋の光を投げかけ た。“個”への回帰願望.—これこそが制作現場 におけるマルチメディア化への潜在的な動機ではない だろうか．映像作家，グラフィックデザイナ，音楽 家，プログラマ……ど, 各分野のスペシャリストや クリエータたちによる自由なコラボレーションを発想 の基とした制作環境の再構築である.

アニメータもついに“個”の復権が望まれる日が来 た。もちろんアニメー夕個人を論じるにしても，量の 問題は避けられない。㧈そらくアニメー夕と動画制作 システムとの新しい関係が，彼らの “個”の復権の鍵 をにぎると思われる。

一方，“アニメ”は“アニメーション”のマルチメ ディアを舞台とした武者修業の成果を吟味して取り入 れていくと思われる。それはあたかもコンピュータソ フト間のリンクで進化していくワープロソフトの新機 能を，市場と照らし合わせて慎重に取り入れていくワ ープロ機のようである. “アニメ”におけるマルチメ ディアの直接的な恩恵は, 制作システムの改変より も，むしろ光ケーブルや双方向テレビなど, 商品流通 にかかわる変化の方がよりリアルかもしれない.

\section{3.「銀河の魚」における DTA の実例}

これまで“アニメ”と“マルチメディア”について 触れてきたが，実際にはそれぞれが持つ本質が根本的 に違うことから，その距離をはかるのはかなり難しい 作業である。そしてまた, 私自身も八イビジョン・ア ニメーション作品 “銀河の魚” の実制作を通してその 矛盾を実際に体感した。 DTA (デスクトップアニメー ション）と呼ばれるコンピュータを導入した制作シス テムで，劇場レベルのアニメーション作品制作に挑戦 したのだ。それも Macintoshでハイビジョンという 無謀な試みである. DTA 作品「銀河の魚」をアニメー ションへのコンピュータの導入の実例として取り上げ る中で, “アニメ”と“マルチメディア”という本テ ーマに関して，より具体的なヒントを感じてもらえた ら幸いである。

\subsection{DTA の作業工程}

$\mathrm{HD}$ 版「銀河の魚」は 1992 年 4 月から 1993 年 4 月 まで丸 1 年を実制作に費やしたハイビジョンアニメー ション作品 (23 min.) である.セルは一切使わず DTA により制作された。主なスタッフ構成は監督・脚本他, 作画監督, 美術監督, キャラクタは原作のたむらしげ る氏， 3 人のコンピュータデザイナ， 6 人の原画マン， 3 人の動画マンである. 現場のディレクタ・プロデュ
たむらしげるアトリエ

\section{SONY HDVS Monitor}

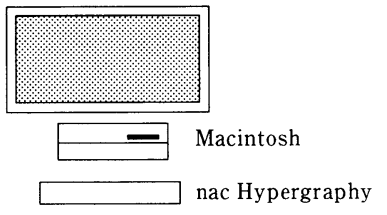

愛があれば大丈大用賀スタジオ



図 1 HD アニメーション作品「銀河の魚」ハードウ エ概略戍

ーサは私が行ったが，原画・動画のラインはプロジェ クトチーム・サラの上田氏が担当した。 その他, 随時 作業工程にあわせて $3 \sim 4$ 人のアシスタントに手伝っ てもらった。

作業は弊社のコンピュータルームが中心となり，そ こに 4 セットの Macintosh とハイビジョンシステム が置かれた (図 1 参照)．作業工程は，まず，たむら氏 が絵コンテと 127 カットのレイアウト原画をあげると ころから始まった．随時原画マンとミーティングを重 ね，タッチを確認しあう。上がった動画は弊社でスキ ヤニングされ，その時点からコンピュータデザイナに よるペーパレスのディジタル作業になる．

たむら氏が Macintosh 上で色をつけたレイアウト 原画を光磁気ディスクでもらい，スキャニングした動 画 1 枚 1 枚にカット固有の 256 色パレットが自動的に はり付けられる. Macintoshでハイビジョンを動か すのはかなり無理がある作業なので，色数を 256 色に 落とさざるを得ない. Macintosh上でペイントされ た動画はSmartScrap 経由で MacroMediaDirector に呼び込まれ，アニメーションの組み立てが行われ る.この時点で動画という感覚から, キャストと呼ば れるオブジェクトとして扱われるようになる。 
組み立てられたアニメーションには, 最終イメージ の確認をしながらのドット単位の光の効果や修正が, 納得いくまで加えられる。これは既存のセルアニメに はありえない作業で, 逆にどこまでやるかの判断が非 常に難しい. 特に, 八イビジョンでのダイレクトな映 像はきめが細かく“動く印刷物”といえるほどのクオ リティで, 手を加えだすときりがないのだ.

3 人のコンピュータデザイナと私で Macintosh に かじりつき, 粘りに粘った末, 実制作開始後 1 年目に して時間切れ，というのが実情であった。

重要なのは, この「銀河の魚」が当時, 音楽と映像 のディレクタ・プロデューサだった私とイラストレー 夕・絵本作家のたむらしげる氏による自主企画だった ということである．私達二人をはじめとして，アニメ 一夕以外はすべてアニメ業界外の人間である，既存の システムに作品をあてはめるよりも, システム自体を 作りたい作品イメージに合わせてカスタマイズしたの だ. 結果として, 少人数工房制が実現できる上記のよ うな DTA システムを考えだしたのである。

少人数工房制とは, 限りなく個人主義に近いチーム ワーク，いわゆる音楽でいう“バンド”のようなもの である。もちろんアニメータたちは上田氏のプロデュ ースの元, コラボレーションの “個”として認識され, スペシャリストとしての感動と手応えがあった．

\section{2 ディジタルならではのメディア展開}

さて, この HD版「銀河の魚」の素材マザーは 13 $\mathrm{GB}$ 分の 20 枚の 5 inch MO から抜粋され, 記録され た CD-ROM 8 枚である. ハイビジョンサイズ $(1920$ ×1035）の画素数でオブジェクト単位のままディスク 保存されたアニメーション素材とは贅沢な話である. 当然, 他メディアへの展開がもちあがる.ディジタル
情報からの直接製版による絵本, HD からのキネコに よる上映用 $35 \mathrm{~mm}$ フィルム, 新録を追加したサウン ドトラック CD アルバム, Macintosh 用の CD-ROM タイトル，もちろん HD版からのダウンコンバート によるNTSC ビデオカセット・LDも発売された。

\section{3 “個”と “組織”}

DTA からメディア展開まで一見いいことばかりの ように見えるが，現実は新たな問題を生んだ．コンピ ュータデザイナたちの個人負担があまりにも重すぎる のだ．セル以降の作業を 3 人のデザイナに置き換える のだから当然である.コンピュータが得意なオリジナ ルパレットの複製や動きのシミュレーションなどはい いとしても, ドット単位の修正作業などは“コンピュ ータで手作りアニメーション”といった方が妥当であ ろう。しかも 1 年間に 1 本の仕事ではやっていけな い. “個”の発想をかかげても弊社はプロダクション であり，組織であることは拭えない。最低限の仕事量 はこなさなければならない。一度はあこがれ，実践し てみた少人数工房制であるが，現在は “個”と“組織” の間を微妙に摇れながら, マルチメディアプロダクシ ヨンの運営の難しさに試行錯誤しているのが現状であ る.

(1994 年 6 月 30 日受付)

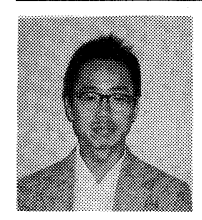

潮永势光生レコードメーカーのディレク 夕一を経て, 昭和 61 年, 共同で (株) 愛があ れば大丈夫を設立. 音楽制作のかたわらグラ フィックスの映像化を模索.コンピュー夕に よるアニメーション制作にたどりつく. 平成 3 年には空想科学事業部を起こし, CDROM タイトル制作改着手.ビジュアルデザ インとオーディオデザインの融合を目指す， プロデュース作品「銀河の魚」が国際エレク トロニック・シネマ・フェスティバル特別賞、 毎日映画コンクール大藤信郎賞を受賞. 